\title{
Research on the coupling effect of the composite slope geometrical parameters
}

\author{
Yamah Joy Barvor $^{1 \otimes}$, Sher Bacha ${ }^{1,2^{*} \bowtie(\bullet)}$, Cai Qingxiang ${ }^{1 凶}$, Chen Shu Zhao ${ }^{1 凶}$, \\ Nisar Mohammad ${ }^{3 \otimes}$, Izhar Mithal Jiskani ${ }^{1 \otimes}$, Naseer Muhammad Khan ${ }^{1 凶}$

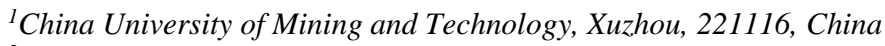 \\ ${ }^{2}$ Baluchistan University of Information Technology, Engineering and Management Sciences, Quetta, 87300, Pakistan \\ ${ }^{3}$ University of Engineering and Technology, Peshawar, 25000, Pakistan \\ *Corresponding author: e-mail engr_shahswati@yahoo.com, tel. +8615262008175
}

\begin{abstract}
Purpose. To analyze the coupling effect between composite slope geometrical parameters.

Methods. The slope angle and excavation depth are coupled with load which is waste dump in this case. Several models were created and analyzed to capture their coupling effect and interactions using FLAC/Slope.

Findings. When the slope angle and excavation depth are coupled with a load such as that of a waste dump, the factor of safety decreases. But a suitable dumping position can prove vital to enhancing stability. The primary cause of this phenomenon is that the stresses induced by the waste dump decrease as the dump is moved away from the crest of the slope and the stress induced within the zone of active wedge beneath the dump reduces on the reference slip plane. Hence, it can be said that the position of the waste dump in the formation of a composite slope plays a key role in enhancing stability. Factor of safety have the same influence pattern for all parameters induced by stress as that of influence rule. The results obtained from the finite element stress analysis are the same with those obtained for the slope stability analysis.
\end{abstract}

Originality. The current research presents for the first time the coupling effect of the composite slope geometrical parameters and the results of finite element stress analysis, which are similar to those of slope stability analysis.

Practical implications. The current research results can be used to effectively analyze and design the composite slopes in soft rocks specially in surface mines.

Keywords: coupling effect, dump, composite slope stability, influence pattern

\section{Introduction}

Slop stability is extremely important in surface structures constructed in or/on the rocks such mines, dams, roads. Different researchers have worked on the slope stability analysis. Composite stability is also important specially in coal mines. Coupling effect of composite slope stability analysis with special focus on surface mine stability is of prime interest. The stability of structures in or/on the rocks are extremely important and if proper design parameters and approaches are not adopted causes disasters which are both dangerous for workers, structures and loss of production [1]-[4]. Different researchers have worked on the slope stability of soft rocks. Finite element analysis has been widely used for the stability of rock slopes. The approach of boundary solution procedures has been introduced as an independent alternative which is more economical and have more advantages. It was shown that how such procedures can be utilized in conventional FEM context. It was also concluded that the FEM-
IDPM has the advantage over limit equilibrium methods that the strain and time-dependent behavior of soil and the staged construction of the slope can be modelled but there is less work done on the coupling effect of geometrical parameters on composite slope stability [5]-[8]. A primary objective of a slope stability analysis is the estimation of a factor of safety for the considered slope and slide mass. The technique of macro-mechanical parameters analysis was used for rock slope analysis and was based on the partition classification method. Critical factor of safety and the prediction of sliding type was analyzed in homogenous and finite slopes. The upper bound limit analysis method under specific conditions was used to develop the slope stability charts [9]-[12].

The approach of geotechnical field survey was used to identify and analyze the unstable slopes. The method of $Q$ slope was applied to slope stability analysis. The Nonlinear Hoek-Brown Criterion utilizing the Equivalent MohrCoulomb Parameters was used for the rock slope stability analysis. A MATLAB code was developed and the efficiency

Received: 13 April 2020. Accepted: 12 April 2021. Available online: 4 June 2021

(C) 2021. Y.J. Barvor et al.

Published by the Dnipro University of Technology on behalf of Mining of Mineral Deposits. ISSN 2415-3443 (Online) | ISSN 2415-3435 (Print)

This is an Open Access article distributed under the terms of the Creative Commons Attribution License (http://creativecommons.org/licenses/by/4.0/),

which permits unrestricted reuse, distribution, and reproduction in any medium, provided the original work is properly cited. 
and accuracy of that MATLAB code was tested by comparison with the exiting results of literature. It was concluded that factor of safety (FS) value showing a decreasing pattern with increasing slope height and angle [13]-[16]. Strength reduction techniques have been implemented for the slope stability analysis. Stable angle and height for the dump was suggested [17]. The results couldn't address the composite slope stability.

Finite element analysis was used for slope stability analysis as compared to traditional equilibrium limit methods and established new standards in the field of geotechnical engineering. The approach of two-dimensional slope stability analysis by limit equilibrium combined with strength reduction techniques was used to study the slope stability. It was concluded that the strength reduction method (SRM) is mostly not sensitive to the dilation angle, soil moduli or the solution domain size and these parameters selection is not critical [18]-[21]. However, composite slope stability and coupling effects between geometrical parameters were not being studied. Another approach of probabilistic systems methodology was applied for the stability of slopes and to analyze various factors affecting the stability of rock slopes [22]-[25].

The approach of analysis with integrated shear strength reduction algorithm was applied to ordinary slope stability analysis [26]. For ordinary rock slopes geometrical effects the criteria of three-dimensional strength-reduction finite element analysis was used [27]. Shear strength reduction technique of finite element was applied to the slope stability analysis [28]. It was attempted to study the slip surfaces stability [29]. The weathering effect on soft rock slopes was analyzed [30]. In another study it was investigated to correlate the effect of materials spatial variability on the soft rock slope stability [31].

An extensive analysis of the literature reveals that composite slope stability is a complex process and therefore remained a hot topic for the researcher. It is also revealed from the literature that coupling effect of composite slope geometrical parameters have not been thoroughly studied. An institutional formulation for the factor of safety, appropriate for a composite slope analysis has been presented in this paper. The dump position, dump height, dump angle, slope angle and excavation depth are key factors that influences the stability of a composite slope. The basic influence rule caused by these geometrical parameters on the stability of composite slope has been highlighted; however, the impact and interaction among these parameters are investigated and put forwarded.

\section{Materials and methods}

The physical-mechanical parameters used in these models are from the surface mine site of the Datang surface coal mine located within the eastern part of Shengli coalfield, a project of Datang international power generation Co., LTD located in Xilingol league, Inner Mongolia autonomous region is used as a case study [1]. The slope angle and excavation depth are coupled with load which is waste dump in this case. Several models were created and analyzed to capture their coupling effect and interactions using FLAC/Slope.

The detailed methodology used in the current research work can be breakdown as under:

- coupling effect between surface mines geometrical parameters and stability of composite slopes;

- improvement in FS, excavation depth and slope angle coupling relationship;
- coupling effect between waste dump geometrical parameters on composite slope stability;

- improvement in FS due to dump height and dump angle coupling interaction;

- coupling effect between dump height and surface mines geometrical parameters;

- improvement in stability due to dumping height and surface mines coupling interactions;

- coupling effect of dump position and dump geometrical parameters on composite slope;

- improvement in stability due to dump height and dump geometrical parameter coupling interactions;

- coupling effect of dump position and surface mines geometrical parameters on composite;

- improvement in stability due to dump position and surface mines geometrical parameter coupling interactions.

\section{Results and discussion}

\subsection{Coupling effect between surface mines geometrical parameters and stability of composite slopes}

The stability of near surface structure is governed by the rock intact structure, whereas, deeper excavations can be more affected by the intact rock and the pre-existing stresses. Failures may be costly in the extreme and have tragic personal consequences. Steep slopes are favourable to the economics of surface mines, while low slope angles favour stability. The trade-off between these two trends almost always results in some failures in large surface mines. This section focuses on the coupling relationship between a surface mines slope height and its angle. These two parameters are the major determinants of slope stability. However, when a waste dump is placed on the crest of a slope, the system becomes a composite slope rendering the mines height as the excavation depth. The surface mines slope reaches the waste dump slope bottom line by distance $d$ and the composite slope direct functional relationship is difficult to accurately measure due to its multiple parameters. However, given the dump position $d=10 \mathrm{~m}$, dump height $\Delta H=20 \mathrm{~m}$, dump angle $\theta=33^{\circ}$, $\psi_{f}$ and $H$ are successively interchanged, the coupling effect of the excavation depth and slope angle can be obtained.

The excavation depth and factor of safety influence rule is established for different slopes angles as shown in Figure 1. The general trend obtained from the analysis results is such that the excavation depth has an inverse relationship to the factor of safety. Even though the overall results indicate a downward trend in the FS values, it can be seen that when the slope angle $\psi_{f}=20^{\circ}$, higher FS is obtained than for $\psi_{f}=25^{\circ}$; similarly, $\psi_{f}=30^{\circ}$, produces higher factor of safety than $\psi_{f}=35^{\circ}$.

Therefore, lower slope angles produce higher FS values than slope with steeper angles. It can also be seen from Figure 5-1, that for each angle, the factor of safety FS converges at lower excavation depths and scatter outwardly as the excavation depth increases. This phenomenon is mostly due to influence of other geometrical parameters when the excavation depth is low. The results spread out at higher excavation depth because at greater depth the excavation depth becomes the controlling factor influencing stability. The analysis results shows that there exists a critical breaking point in the FS value due to variation in the excavation depth which serves as the vertex of a parabola curve which opens sideways. 


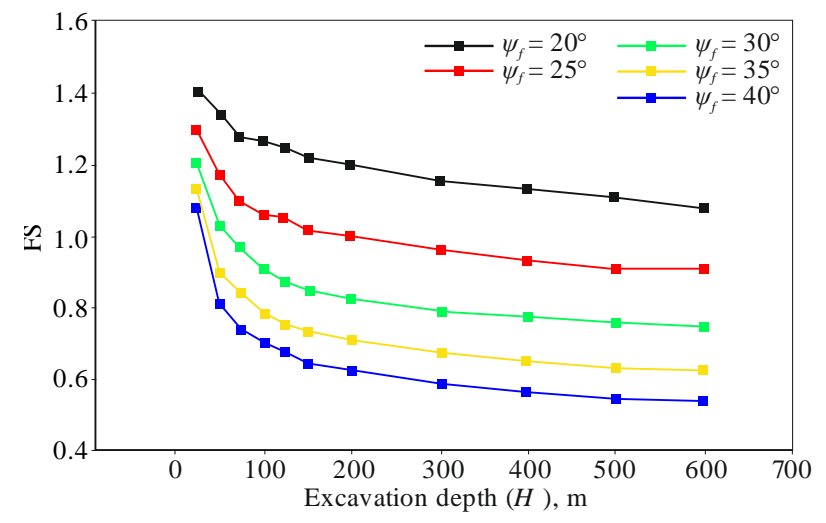

Figure 1. Coupling rule for different excavation depth at different slopes angles

For $\psi_{f}=20^{\circ}$ the critical breaking point related to the excavation depth is $H=75 \mathrm{~m}$ and $H=125 \mathrm{~m}$ for $\psi_{f}=25^{\circ}$. As the slope angle increases these breaks within the trend of the FS values diminish forming a more perfect parabolic shape. Practically, this phenomenon occurs due to the change in critical parameter that control stability. Figure 2 shows the slope angles and factor of safety influence rule for different excavation depths. It can be seen from the group of curves that the FS values show a consistent decrease pattern when the slope angle increases for each excavation depth.

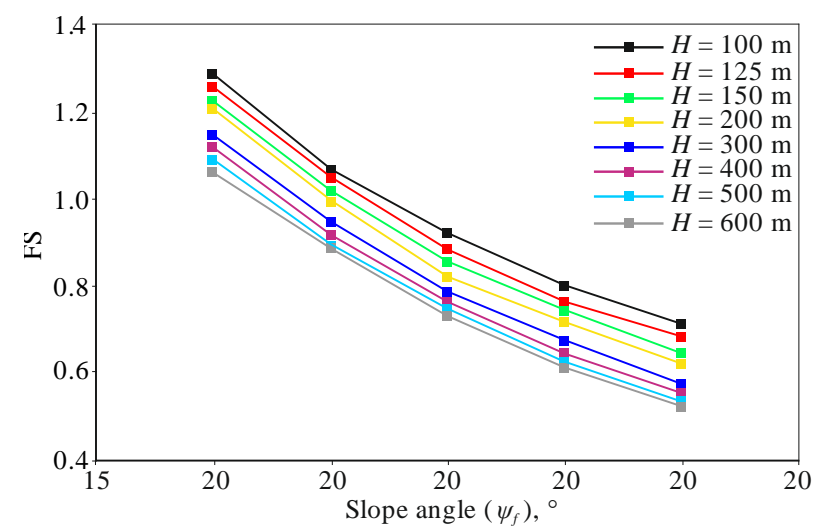

Figure 2. Influence rule for different slopes angles at different excavation depth

The general influence rule obtained is such that the slope angle is inversely proportional to the factor of safety; however, when the excavation depth $H=100 \mathrm{~m}$, higher FS values are obtained than for $H=125 \mathrm{~m}$. Similarly, when the excavation depth is further increased to $H=300 \mathrm{~m}$ far lower FS value is obtained than the previous two cases $(H=100 \mathrm{~m}$ and $H=125 \mathrm{~m}$ ). Therefore, higher excavation depth produces lower FS values and lower excavation depth produces higher FS values. Hence, these parameters have functional relationship that when understood can greatly improve stability and the economic profitability within any given surface mine.

\subsection{Improvement in FS, excavation depth and slope angle coupling relationship}

The factor of safety of a composite slope decreases when the excavation depth and slope angle are jointly increased. However, it is obtained that by considering the coupling interaction amongst these parameters can greatly improve the factor of safety. Figure 3 illustrates a 3D Data plot of the excavation depth, and slope angle as contour outlines in 2D space.

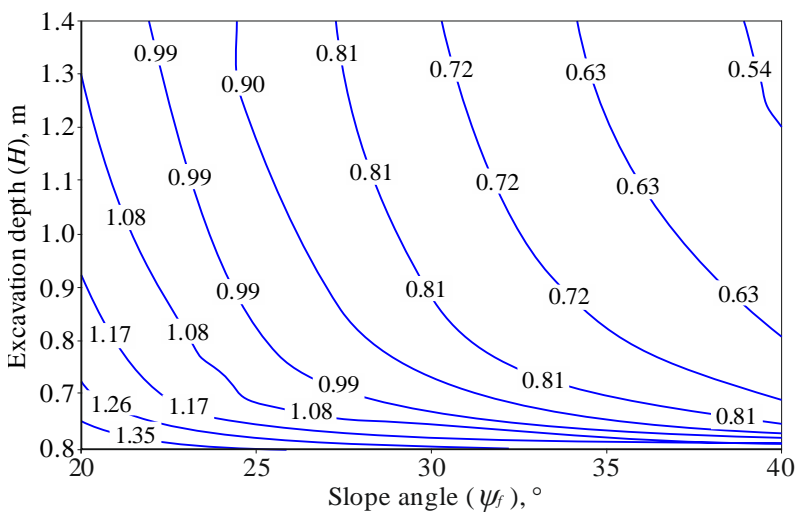

Figure 3. 3D Data plot of excavation depth, and slope angle as contour outlines in $2 D$ space

In Figure 3, the vertical axis represents the excavation depth while the $\mathrm{x}$-axis represents the slope angle. Moving along the vertical axis from the point of origin $(20,0)$, the factor of safety decreases with increase in excavation depth while if moving on the $\mathrm{x}$-axis from the point of origin the factor of safety also decreases with increase in slope angle. However, considering an abscissa and ordinate value within the 2D space a conclusion can be drawn that how the FS behaves when these two parameters are coupled.

Firstly, when $H=100 \mathrm{~m}$ and $\psi_{f}=20^{\circ}$ the obtained factor of safety $\mathrm{FS}=1.26$, however when both parameters are increased simultaneously such that $H=500 \mathrm{~m}$ and $\psi_{f}=40^{\circ}$, the obtained FS $=0.54$, thus it can be seen that the coupling of low excavation depth with low slope angle produces higher factor of safety than higher excavation depth and steep slope angles. Secondly, when $H=500 \mathrm{~m}$ and $\psi_{f}=20^{\circ}, \mathrm{FS}=1.08$. Nevertheless, when the slope angle increases from $\psi_{f}=20^{\circ}$ to $\psi_{f}=40^{\circ}$, the factor of safety decreases to FS $=0.54$. Similarly, if the slope angle is maintained at $\psi_{f}=40^{\circ}$ and the excavation depth is reduced to $H=100 \mathrm{~m}$ the resulting factor of safety is improved from $\mathrm{FS}=0.54$ to $\mathrm{FS}=0.72$. Hence, it can be seen, that in order to enhance stability and increase the factor of safety an inverse parametric technique must be employed in order to select the suitable surface mines parameters.

A rule of thumb can be drawn from the assertion made above in order to improve stability within any given surface mine. It means that deep excavation should be created with lower slope angles and steep slope angles with shallower excavation depth. By understanding the influence and changes in the FS values due to the interaction between the surface mines key geometrical parameters can help engineers and managers in making sound decision regarding parametric selection.

\subsection{Coupling effect between waste dump geometrical parameters on composite slope stability}

Surface mining operations involve the removal of huge quantities of overburden, dumping and backfilling. Substantial increase in the rate of accumulation of waste materials in recent years has resulted in greater height of dumps in order to minimize ground cover area and consequently, this has given rise to the danger of dump failures, gully erosion and various associated environmental problems. Inorder to deduce the coupling relationship between the dumping height and the dump angle in a composite slope system several numerical models were analyzed using FLAC/Slope and a finite difference method. According to [1], the composite slope angle relates the different geometrical parameters. 
Given the dump position $d=50 \mathrm{~m}$ slope angle $\psi_{f}=30^{\circ}$ and excavation depth $H=125 \mathrm{~m}$ and the dump angle $\theta$ and dump height $\Delta H$ are successively changed, their coupling interaction and influence on the factor of safety can be established. Figure 4 shows the analysis results for different dump height and FS values at varying dump angles and it can be seen that, when the dump angle $\theta=20^{\circ}$ a higher FS value is obtained than for $\theta=25^{\circ}$. Similarly, when $\theta=30^{\circ}$ the numerical simulation produces higher factor of safety than for $\theta=33^{\circ}$.

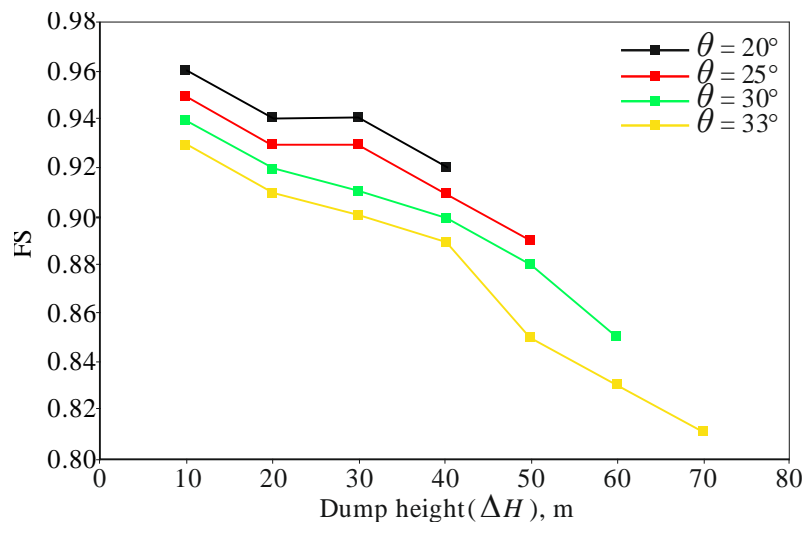

Figure 4. Influence rule for different dumping angles at different dumping height

Therefore, lower dump angles produce higher FS values than dump with steeper angles. The general pattern of the dump height, when coupled with the dump angle shows a decrease in relationship with the factor of safety; When the dump angle $\theta=20^{\circ}$ and $\theta=30^{\circ}$, the critical break point in the FS value falls at $\Delta H=30 \mathrm{~m}$, while for $\theta=30^{\circ}$ the number of break points increases. However, when $\theta=33^{\circ}$, the break point is at $\Delta H=40 \mathrm{~m}$ and the variation pattern changes to a near straight diagonal line which indicates that a control transition between the dump heights and the dump angle is gradually occurring.

The reason for the changes in the curve is such that the magnitude of the dump angle increases with the increase in the dump angle, hence the influence of the dump increases. Another critical aspect when the dump height and dump angle is coupled is such that the maximum dump height is a function of the dump angle. Considering factors such as the number of benches, the maximum height that the dump with angle $\theta=20^{\circ}$ within this study could be constructed was $\Delta H=40 \mathrm{~m}$. Thus, any increment in the dump height would have resulted in the crest of the dump turning into a cone shape.

Figure 5 shows the combined FS and influence rule for different dump angles as the dump height is interchanged. It can be seen from the group of curves that the FS values decrease for each dump height. The overall results indicate a decrease in the FS values however it can be seen that when the dump height $\Delta H=10 \mathrm{~m}$ higher FS values are obtained than for $\Delta H=20 \mathrm{~m}$. Similarly, when the dump height is further increased to $\Delta H=30 \mathrm{~m}$ far lower FS values are obtained from the numerical analysis than the previous two cases $(\Delta H=10 \mathrm{~m}$ and $H=20 \mathrm{~m}$ ). Therefore, higher dump heights produce lower FS values and lower dump height produces higher FS value.

It is also seen from the results, that when $\Delta H=10 \mathrm{~m}$, the factor of safety shows a gradual decline from $\theta=20^{\circ}$ to $\theta=30^{\circ}$ and falls at $\theta=30^{\circ}$, this indicates that for $\theta>30^{\circ}$ the influence of the dump height vanishes and the dump angle becomes the factor controlling the stability of the slope.

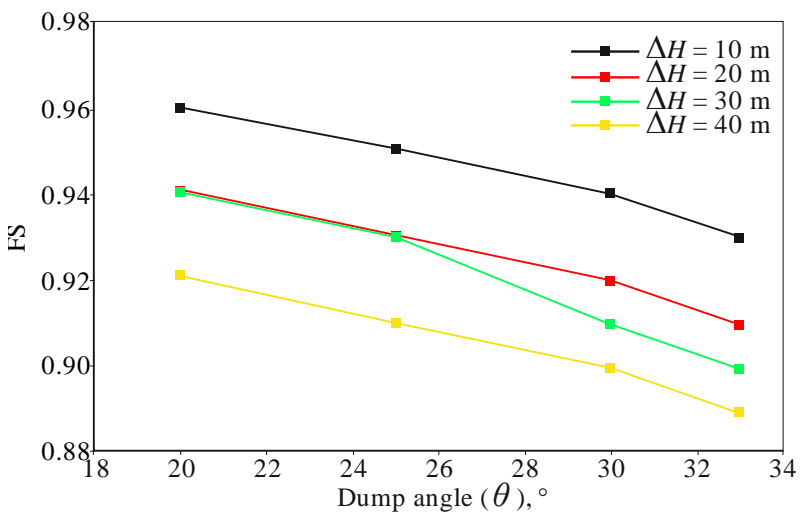

Figure 5. Factor of safety for different dumping height and dumping angles

However, as the dump height increases from $\Delta H=10 \mathrm{~m}$ to $\Delta H=20 \mathrm{~m}$ the FS shows an accelerated decline between $\theta=20^{\circ}$ and $\theta=30^{\circ}$ before falling at $\theta=30^{\circ}$ and the reason is obvious. This indicates that the magnitude of the dump on the stability of the composite slope increases with increase in dump height. Furthermore, as the dump height increases to $\Delta H=30 \mathrm{~m}$ the factor of safety depicts a fall at $\theta=25^{\circ}$ and a continuous decline forming a near straight diagonal line. Similarly, the phenomenon becomes visible for $\Delta H=40 \mathrm{~m}$, an accelerated decline occurs in the factor of safety and falls at $\theta=30^{\circ}$ at the line which becomes straighter than in previous cases. The analysis results has shown that the dump height and angle are two parameters with functional relationship.

\subsection{Improvement in FS due to dump height and dump angle coupling interaction}

The factor of safety decreases with increase in both the dump height and dump angle. However, by considering the coupling interaction between the two parameters in a composite slope system can enhance stability. Figure 6 illustrates a $3 \mathrm{D}$ data plot of the dump angle, and dump height as contour outlines in 2D space.

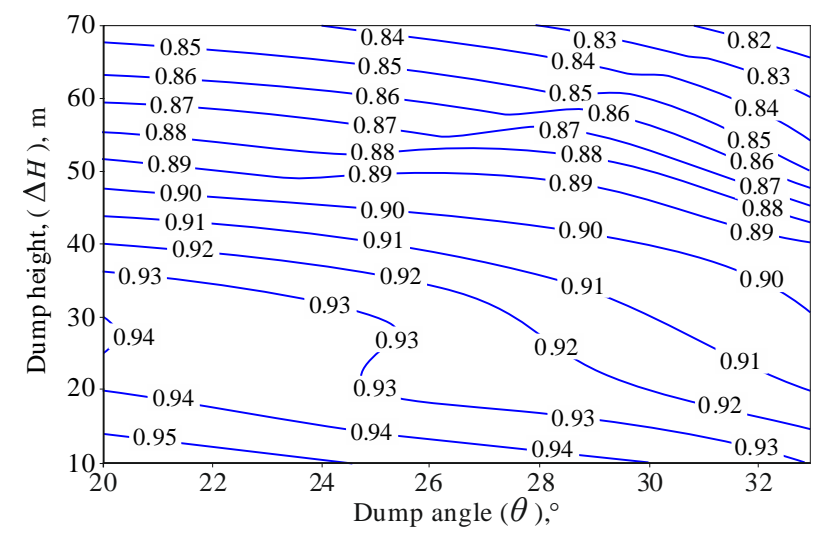

Figure 6. 3D Data plot of dumping height, and angle as contour outlines in $2 \mathrm{D}$ space

In Figure 6, the vertical axis represents the dump height while the $\mathrm{x}$-axis shows the dump angle. Moving along the vertical axis from the point of origin $(20,0)$, the factor of safety decreases with increase in dump height while it decreases along the $\mathrm{x}$-axis with increase in dump angle. Let's consider an abscissa and an ordinate value within the $2 \mathrm{D}$ space in order to draw a conclusion on how the FS behaves when these two parameters are coupled. 
Firstly, when $\Delta H=20 \mathrm{~m}$ and moving along the $\mathrm{x}$-axis where $\theta=20^{\circ}$ the obtained factor of safety $\mathrm{FS}=0.92$, however when both parameters are increased simultaneously such that $\Delta H=40 \mathrm{~m}$ and $\theta=33^{\circ}$ the obtained factor of safety is $\mathrm{FS}=0.85$, thus it can be seen that the coupling of low dump heights with shallower dump angles, produces higher factor of safety than higher dump height and steep dump angles. Secondly, when $\Delta H=40 \mathrm{~m}$ and $\theta=20^{\circ}$ the factor of safety $\mathrm{FS}=0.88$, nevertheless when the dump angle increases from $\theta=20^{\circ}$ to $\theta=33^{\circ}$, the factor of safety decreases to $\mathrm{FS}=0.85$. Similarly, if the dump angle is maintained at $\theta=33^{\circ}$ and the dump height is reduced to $\Delta H=20 \mathrm{~m}$ the resulting factor of safety is improved from $F S=0.85$ to $\mathrm{FS}=0.91$. It can be seen from the results that in order to enhance stability and increase the factor of safety when the dump height and dump angle are the determinant factors influencing stability in a composite slope system an inverse parametric technique must be employed in order to select suitable dump parameters. Therefore, it can be concluded that the two key geometrical parameters of a waste dump are important factors influencing the stability of a composite slope and that the coupling interactions between these parameters can improve the factor of safety significantly.

\subsection{Coupling effect between dump height and surface mines geometrical parameters}

This section seeks to evaluate and understand the coupling relationship between the dump geometrical parameters to that of the foundation slope. In order to deduce the coupling relationship between the dumping height and the slope geometrical parameters (slope angle and excavation depth) several numerical models were analyzed using the finite difference method employed in FLAC/Slope. As discussed in section 3.4 , the composite slope angle relates the different geometrical parameters within the system. Given the dump position $d=10 \mathrm{~m}$, dump angle $\theta=33^{\circ}$ and the excavation depth $H$, slope angle and the dump height $\Delta H$ are successively interchanged and their influence on stability can be obtained along with their coupling interaction on the factor of safety.

The influence rule for the key geometrical parameters of a given surface mine and the factor of safety is established for different dumping heights. The numerical analysis results shows that the slope parameters in the formation of a composite slope have an inverse relationship to the factor of safety. The factor of safety decreases with increase in both excavation depth and slope angle. Figure 7a, b shows the analysis results for different composite slope model analyse at different surface mines parameters and dumping heights. From Figure 7a, when the dump height $\Delta H=20 \mathrm{~m}$ a higher FS values are obtained than for $\Delta H=30 \mathrm{~m}$. However, when $\Delta H=40 \mathrm{~m}$, the numerical simulation produces higher factor of safety than for $\Delta H>40 \mathrm{~m}$. Figure $7 \mathrm{~b}$ depicts similar trend in the FS value even when the dump height is coupled with the slope angle. Therefore, lower dump heights produce higher FS values than dump with higher heights in a composite slope system.

Even though an inverse relationship is established when the dump height is coupled with the excavation depth and slope angle, the influence rule between these parameters are significantly different (Fig. 7a, b). According to the theory of vertical stresses in a rock mass, the induced stresses reduces in magnitude with depth, however the stress induced will reach a maximum value that is equivalent to the surcharge load. (a)

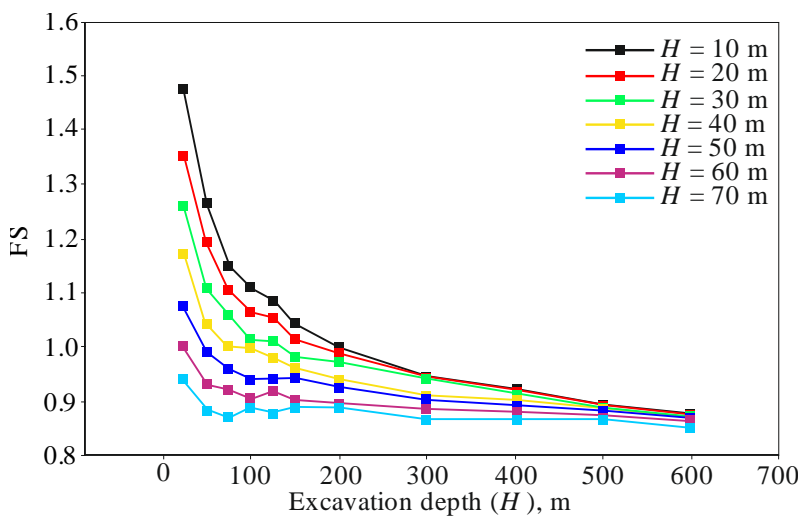

(b)

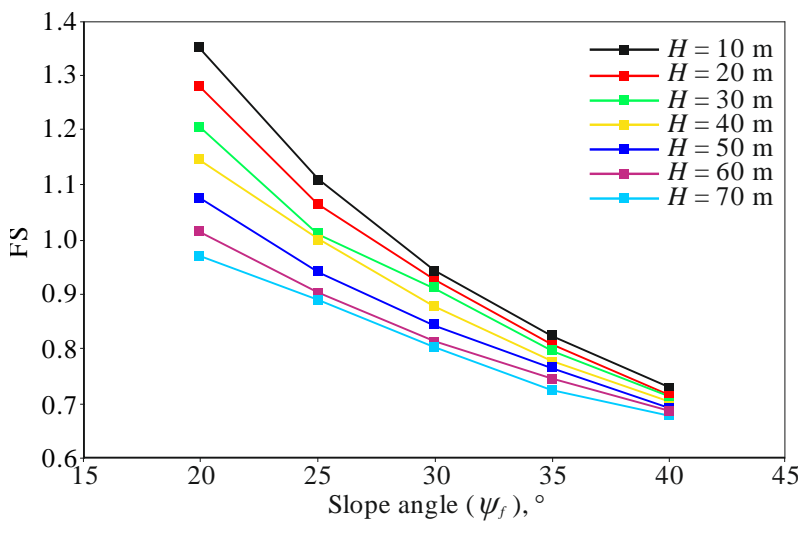

Figure 7. Factor of safety for different excavation depth and slope angle at varying dumping heights

When this happens the competition for control occurs within the rock mass as the stresses induced by the magnitude of the surcharge is resisted by the pre-existing stresses within the excavation. This phenomenon can actually be seen in Figure 7a, where there exists a break point in each curve. Furthermore, when the equivalent surcharge due to the dumping height is excessive further deformation occur within the system due to the loading height but if the opposite occurs then the FS will tend to rise to the original FS value when the slope has no surcharge and takes a decrease pattern if the excavation depth are to be increase.

It can also be seen from Figure $7 \mathrm{a}, \mathrm{b}$ that the FS converge at a constant value when the dumping height is coupled with the slope geometrical parameters. Figure $8 \mathrm{a}, \mathrm{b}$ shows the dump height influence rule for different excavation depths and slope angles. The general influence pattern obtained from the analysis is such that the dump height is inversely proportional to the factor of safety. From Figure 8a, it can be seen that when the excavation depth $H=25 \mathrm{~m}$ higher FS values are obtained than for $H=50 \mathrm{~m}$ and when the excavation depth is further increased to $H=75 \mathrm{~m}$ much lower FS values are obtained from the numerical analysis than in the previous two cases $(H=25 \mathrm{~m}$ and $H=50 \mathrm{~m})$.

Therefore, greater excavation depths produces lower FS values and lower excavation depths produces higher FS value. Similarly, Figure $8 \mathrm{~b}$ shows that when the slope angle $\psi_{f}=20^{\circ}$ higher FS values are obtained than for $\psi_{f}=25^{\circ}$ and when the slope angle is further increased to $\psi_{f}=30^{\circ}$ much lower FS values are obtained from the numerical analysis than when $\psi_{f}=20^{\circ}$ and $\psi_{f}=25^{\circ}$ respectively. 
(a)

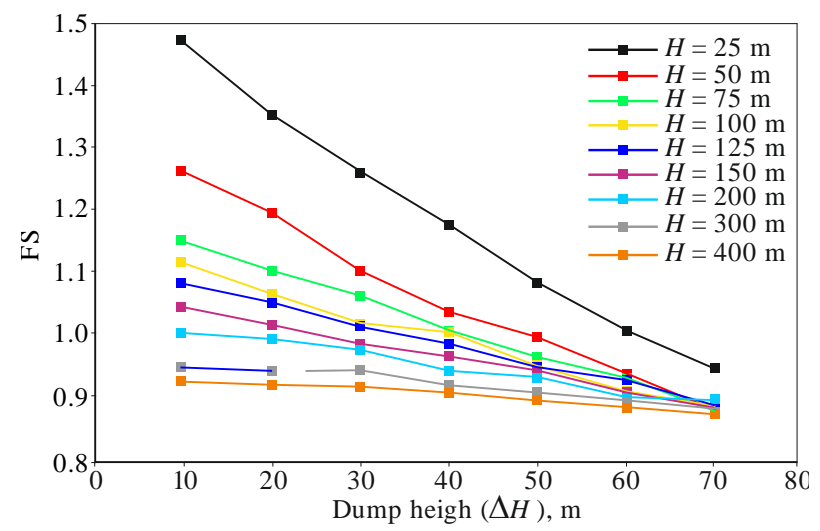

(b)

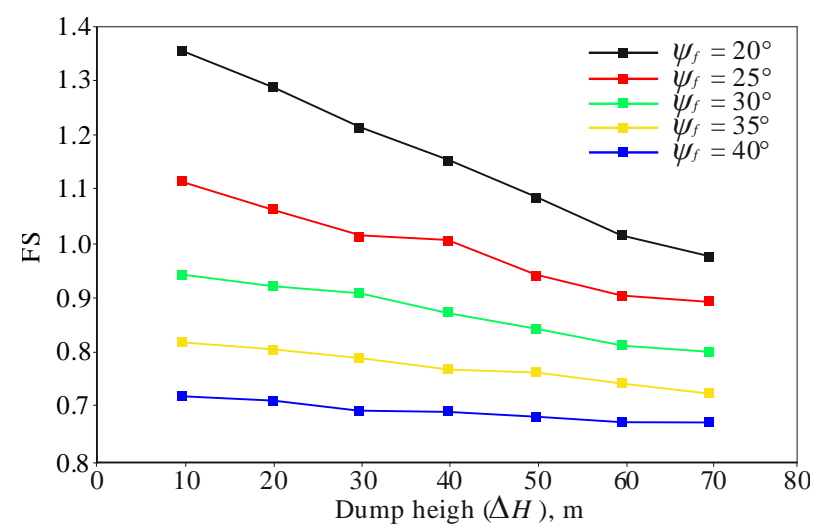

Figure 8. Factor of safety for different dumping height at varying excavation depth and slope angle

Therefore, steeper slope angle produces lower FS values and lower angles produce higher FS value. As discussed earlier, Figure 8a shows that the FS value converges to a single value when $\Delta H=70 \mathrm{~m}$ indicates an influential break point where the dump height has a significant influence on the factor of safety.

\subsection{Improvement in stability due to dumping height and surface mines coupling interactions}

By understanding the influence and changes in the FS values due to the interaction between the dumping height and the surface mines key geometrical parameters, engineers and managers can make sound decision regarding parametric selections that govern stability.

Figure 9a, b illustrates a 3D data plot of the dump height, and surface mines geometrical parameters as contour outlines in 2D space. In Figure 9a, the vertical axis represents the dump height while the $\mathrm{x}$-axis shows the excavation depth. As moving along the vertical axis from the point of origin (20, 10), the factor of safety decreases with increase in dump height while it decreases along the $\mathrm{x}$-axis with increase in excavation depth.

Similarly, it is seen from Figure 9b, moving along the vertical axis from the point of origin $(20,10)$, the factor of safety decreases with increase in dump height and decreases along the $\mathrm{x}$-axis with increase in slope angle. However, let's consider an abscissa and ordinate values within the 2D space in order to draw a conclusion on how the FS behaves when the dumping height is coupled with the excavation depth. (a)

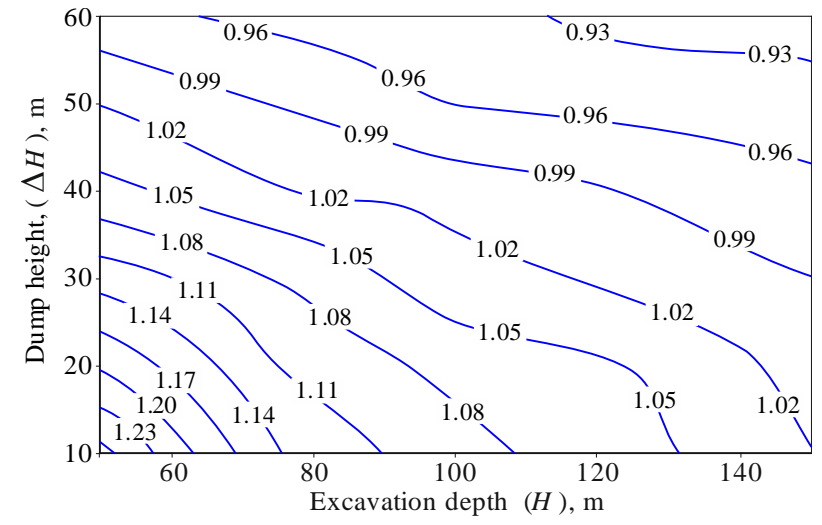

(b)

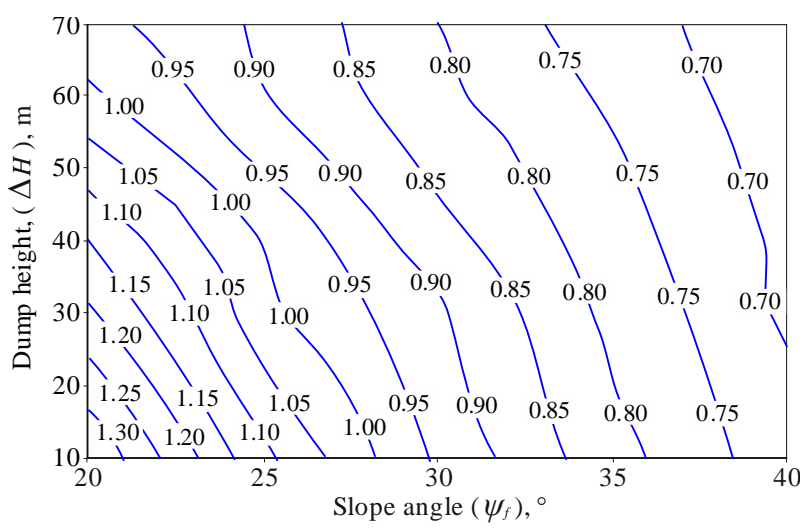

Figure 9. 3D data plot of dumping height, and excavation depth as contour outlines in $2 \mathrm{D}$ space

Firstly, from Figure 9a, when $\Delta H=20 \mathrm{~m}$ and moving along the $\mathrm{x}$-axis were $H=100 \mathrm{~m}$ the obtained factor of safety $\mathrm{FS}=1.08$, however when both parameters are increased simultaneously such that $\Delta H=60 \mathrm{~m}$ and $H=150 \mathrm{~m}$ the obtained factor of safety is FS $=0.93$, thus it can be seen that the coupling of low dump heights with lower excavation depth, produces higher factor of safety than higher dump height and higher excavation depth. Secondly, when $\Delta H=50 \mathrm{~m}$ and $H=150 \mathrm{~m}$ the factor of safety $\mathrm{FS}=0.96$, nevertheless when the excavation depth decreases from $H=100 \mathrm{~m}$ to $H=60 \mathrm{~m}$, the factor of safety increase to FS $=1.02$. Similarly, if the excavation depth is maintained at a constant depth of $H=60 \mathrm{~m}$ and dump height is increased to $\Delta H=60 \mathrm{~m}$ the resulting factor of safety decreases from $\mathrm{FS}=1.02$ to $\mathrm{FS}=0.96$.

Hence, it can be seen from the results that in order to enhance stability and increase the factor of safety when the dump height and dump angle are the determinant factors influencing stability in a composite slope system an inverse parametric technique must be employed in order to select suitable dump height and excavation depth.

A similar descriptive analysis can be done from Figure 9b, to draw a conclusion on how the FS behaves when the dumping height is coupled with the slope angle. It can be seen from the Figure $9 \mathrm{~b}$ that at a constant excavation depth, a lower slope angle and lower dump height will produce a higher factor safety than a composite slope with a high dump heights and steep slope angles. The results also shows that a high dump heights coupled with shallower slope angles will produce comparatively better factor of safety than upper limits 
between the both parameters. Finally, it can be concluded that by understanding the coupling interactions between the upper and lower limits of the surface mines geometrical parameters and the dumping heights can improve the factor of safety significantly; thus, the stability of the system.

\subsection{Coupling effect of dump position and dump geometrical parameters on composite slope}

This section seeks to understand the coupling relationship between the dump geometrical parameters and the dump position in a composite slope system by using FLAC/Slope, a finite difference method. According to [1], the composite slope angle relates the different geometrical parameters. Given the slope angle $\psi_{f}=20^{\circ}$ and excavation depth $H=100 \mathrm{~m}$ and the dump position $d$, dump angle $\theta$ and dump height $\Delta H$ are successively changed, their coupling interaction and influence on the factor of safety can be established. The influence rule for the key geometrical parameters of a waste dump and the factor of safety is established for different dump position. Figure 10a, b shows the analysis result for different dump geometrical parameters and varying dump position, while Figure 11a,b shows the analysis result for different dump position and varying dump angles and dumping height.

(a)

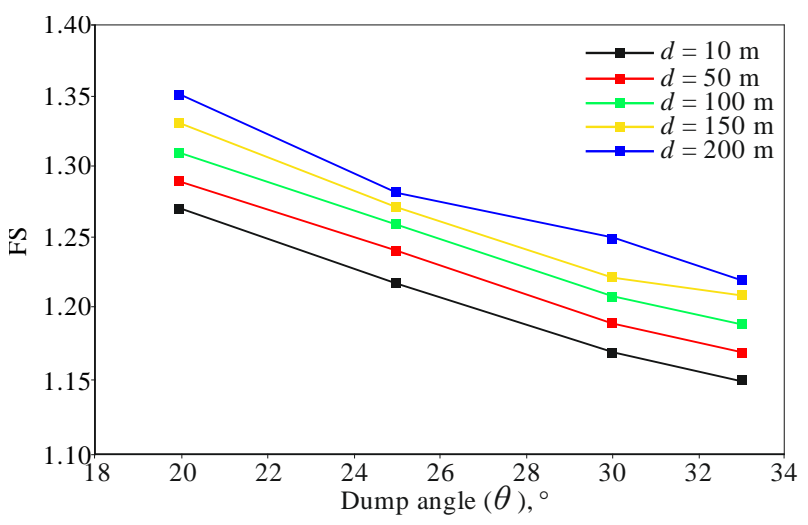

(b)

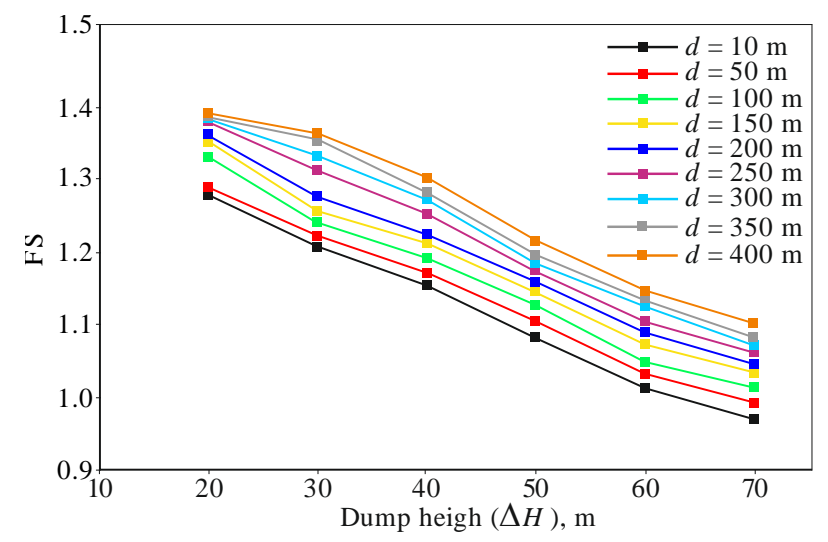

Figure 10. Factor of safety for different dumping height and dump angle at varying dump position

From Figure 10a, b it can be seen that the dump key geometrical parameters in a composite slope system have an inverse relationship to the factor of safety. It means the factor of safety decreases with increase in both the dump height and dump angle. However, it can be seen from Figure 11a, b, that the dump position has a direct relationship with the factor of safety. (a)

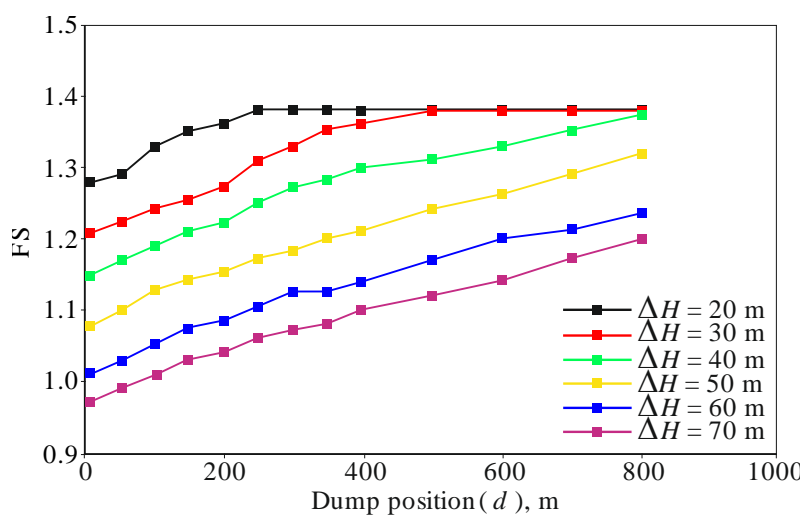

(b)

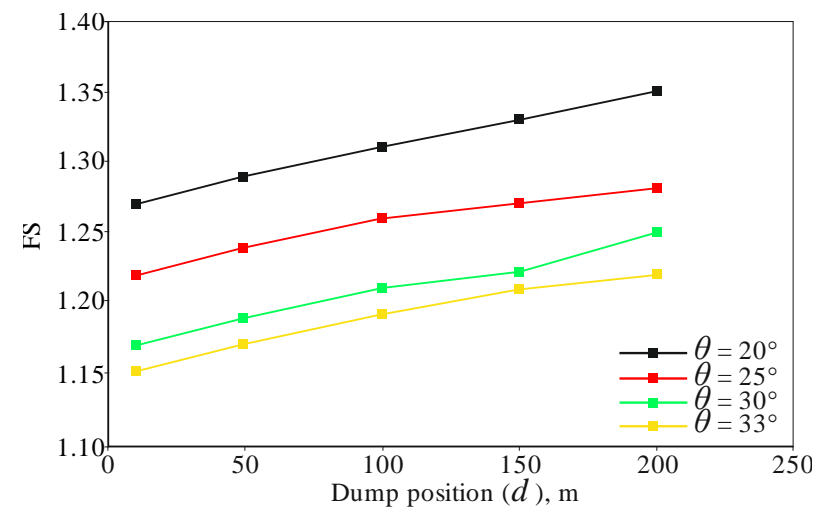

Figure 11. Factor of safety for different dump position at varying excavation depth and slope angle

From Figure 10a, it is seen that when the dump position $d=100 \mathrm{~m}$ lower FS values are obtained than for $d=150 \mathrm{~m}$. However, when $d=200 \mathrm{~m}$, the numerical simulation produces higher factor of safety than for $d<200 \mathrm{~m}$. Figure 10b depicts similar trend in the FS value when the dump position is coupled with the dump angle. Therefore, lower dump position produces lower FS value than dump with great distances away from the crest of a surface mines in a composite slope system.

From Figure 12a, it is seen that when the dump height $\Delta H=20 \mathrm{~m}$ higher FS values are obtained than for $\Delta H=30 \mathrm{~m}$. However, when $\Delta H=50 \mathrm{~m}$, the result shows lower factor of safety than for $\Delta H<50 \mathrm{~m}$. Figure $11 \mathrm{~b}$ depicts similar trend in the FS value when the dump position is coupled with the dump angle. Therefore, lower dump height and dump angle produces higher FS than dump with steep angle and high dump height within a composite slope system. According to the theory of vertical stresses in a rock mass, the application of a surcharge induces additional stresses within a rock mass and if the magnitude of the surcharge is excessive deformation of the rock mass will occur.

Hence, it is expected that the increase in the dumping height and dump angle will induce additional stress thereby resulting in the reduction of the factor of safety as seen in Figure 10a, b. Similarly, according to the theory of vertical stresses in a rock mass, the induced stress due to a surcharge reduces in magnitude away from the point of application. Hence, in a composite slope system, it is expected that the factor of safety will increase as the load is moved away from the crest of the slope as that shown in Figure 11a,b. Furthermore, the results shown in Figure 11a shows a direct 
relationship between the dump position and FS when coupled with the dump height, however the influence rule between these parameters are significantly different.

From Figure 11a, it can be seen that when $\Delta H=20 \mathrm{~m}$ the maximum safe distance is $d=250 \mathrm{~m}$. From this position the factor of safety remains constant for $d \geq 250 \mathrm{~m}$ and the magnitude of the dump with $\Delta H=20 \mathrm{~m}$ has no influence on the stability of the system. However, when the equivalent surcharge due to the dumping height is increased from $\Delta H=20 \mathrm{~m}$ to $\Delta H=30 \mathrm{~m}$ the maximum safe distance is $d=450 \mathrm{~m}$ and from this position the factor of safety remains constant for $d \geq 450 \mathrm{~m}$. For dump height $\Delta H \geq 40 \mathrm{~m}$, the influence rule shows constant increase in the value of the factor of safety indicating that the magnitude of dumping height yet influences the stability of the system. Hence, it can be said that the influence of the dump position is a function of the loading condition.

\subsection{Improvement in stability due to dump height and dump geometrical parameter coupling interactions}

By understanding the influence and changes in the FS values due to the interaction between the dump position and the dump key geometrical parameters, the stability of a composite slope can be enhanced greatly. Figure 12(a-b) illustrates a 3D data plot of the dump position, and dump key geometrical parameters as contour outlines in 2D space. In Fig 12a, the vertical axis represents the dump position while the $\mathrm{x}$-axis shows the dumping height. Moving along the vertical axis from the point of origin $(20,0)$, the factor of safety increases with increase in dump position while it decreases along the $\mathrm{x}$-axis with increase in dumping height. Similarly, it is seen from Figure $12 \mathrm{~b}$, moving along the vertical axis from the point of origin $(20,0)$, the factor of safety increases with increase in dump position and decreases along the $\mathrm{X}$-axis with increase in dump angle.

By considering an abscissa and ordinate values within the 2D space a conclusion can be drawn that how the FS behaves when the dumping height is coupled with the dump position. From Figure 12a, when $d=10 \mathrm{~m}$ and one moving along the $\mathrm{x}$-axis were $\Delta H=20 \mathrm{~m}$ the obtained factor of safety $\mathrm{FS}=1.33$; however, when the dump position is increased to $d=150 \mathrm{~m}$ the factor of safety increases to $\mathrm{FS}=1.37$. If the dump position has to be maintained at $d=10 \mathrm{~m}$ and moving along the $\mathrm{x}$-axis such that $\Delta H=40 \mathrm{~m}$, the obtained factor of safety is $\mathrm{FS}=1.28$, thus it can be seen that the coupling of low dump heights with lower dump position, produces higher factor of safety than higher dump height and lower dump positions. Secondly, when $\Delta H=40 \mathrm{~m}$ and $d=10 \mathrm{~m}$ the factor of safety $\mathrm{FS}=1.28$, nevertheless when the dump position is increased from $d=10 \mathrm{~m}$ to $d=200 \mathrm{~m}$, the factor of safety increases to $\mathrm{FS}=1.35$, indicating that the coupling of high dump height with high dump position significantly increases the factor of safety.

Furthermore, a conclusion can be drawn that how the FS behaves when the dump angle is coupled with the dump position by analyzing Figure 13b. From Figure $12 \mathrm{~b}$, when $d=10 \mathrm{~m}$ and moving along the $\mathrm{x}$-axis where $\theta=20^{\circ}$ the obtained factor of safety $\mathrm{FS}=1.28$; however, when the dump position is increased to $d=150 \mathrm{~m}$ the factor of safety increases to $\mathrm{FS}=1.33$. If the dump position has to be maintained at $d=10 \mathrm{~m}$ and moving along the $\mathrm{x}$-axis such that $\theta=33^{\circ}$, the obtained factor of safety is FS $=1.16$, thus the coupling of low dump angles with lower dump position, produces higher factor of safety than steeper dump angles and lower dump positions. (a)

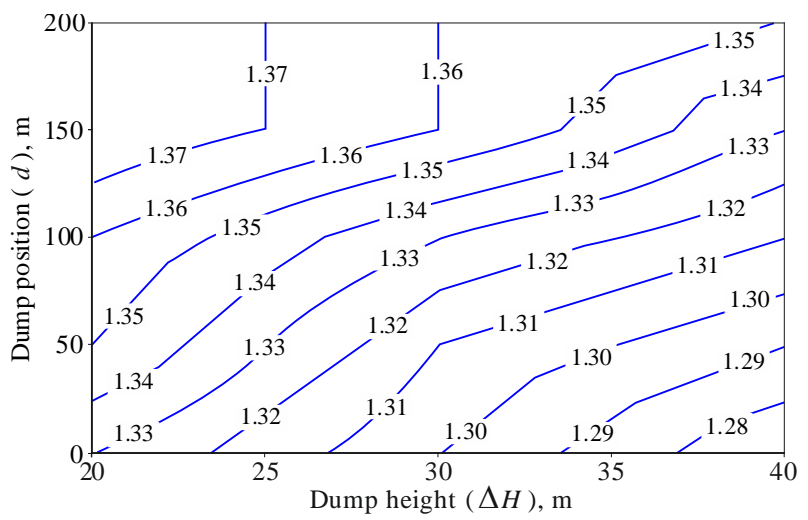

(b)

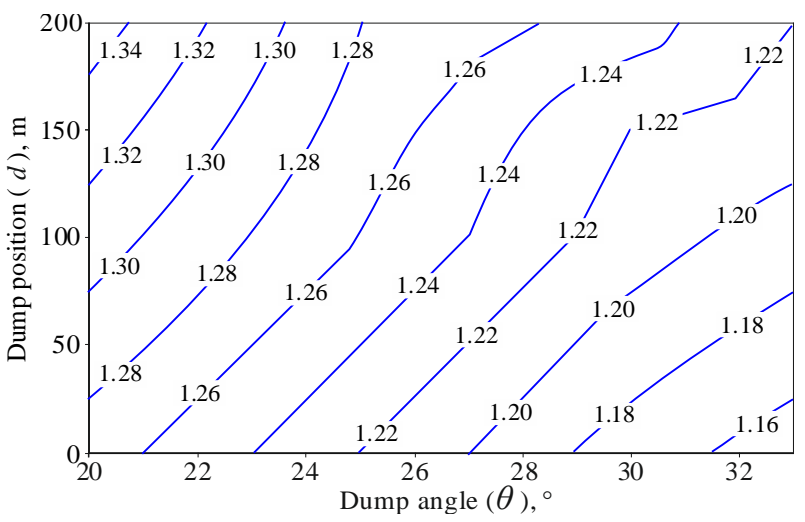

Figure 12. 3D Data plot of dump position, and dump key geometrical parameters as contour outlines in $2 D$ space

Secondly, when $\theta=33^{\circ}$ and $d=10 \mathrm{~m}$ the factor of safety $\mathrm{FS}=1.16$, nevertheless when the dump position is increased from $d=10 \mathrm{~m}$ to $d=200 \mathrm{~m}$, the factor of safety increases to $\mathrm{FS}=1.22$, indicating that the coupling of steep dump angles with high dump position can improve the factor of safety significantly. Hence, it can be seen from the results that in order to enhance stability and increase the factor of safety when the dump key geometrical parameters are the determinant factors influencing stability in a composite slope system the position of the dump within the system plays a critical role.

\subsection{Coupling effect of dump position and surface mines geometrical parameters on composite slope}

An exposed ground surface that stands at an angle with the horizontal is called an unrestrained slope. When an excavation is created such as that of a surface mine, the pre-existing stress state within the ground can dramatically change. This is because rocks which previously contain stresses are removed and the load has to be taken up elsewhere and displacement occurs because stressed rock has been removed, allowing the remaining rock to move due to unloading.

This section seeks to understand the coupling relationship between the surface mines geometrical parameters and the dump position in a composite slope system by using FLAC/Slope, a finite difference method. According to [1], the composite slope angle relates the different geometrical parameters. Given the dump angle $\theta=20^{\circ}$, and dump height $\Delta H=40 \mathrm{~m}$ and the dump position $d$, slope angle $\psi_{f}$ and excavation depth $H$ are successively changed, their coupling interaction and influence on the factor of safety can be established. 
(a)

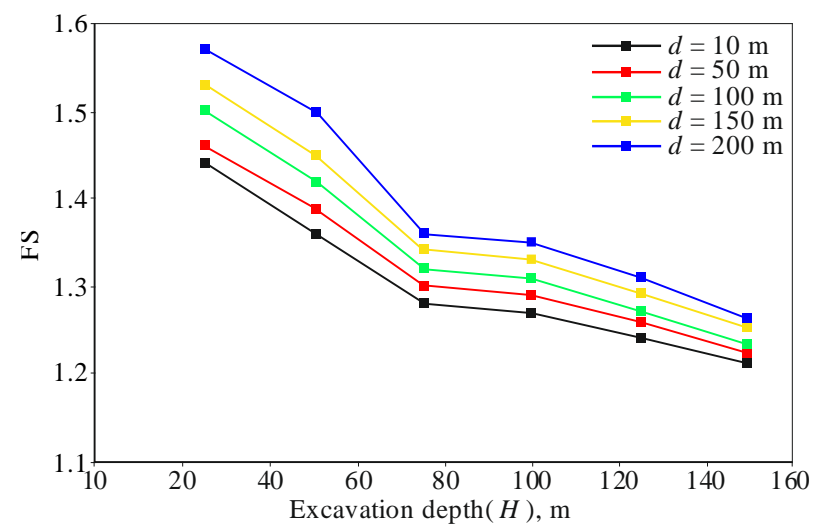

(b)

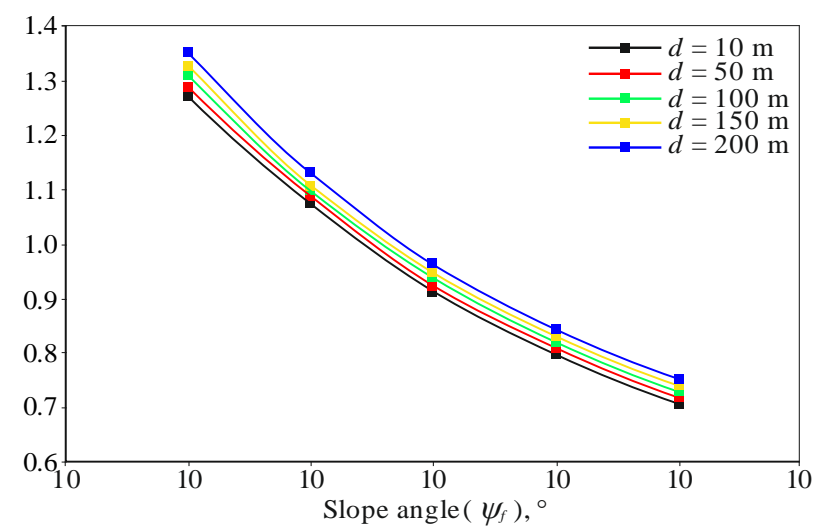

Figure 13. Factor of safety for different excavation depth and slope angle at varying dump position

The influence rule for the key geometrical parameters of a surface mine slope and the factor of safety is established for different dump position. Figure 13a, b shows the analysis results for different slope geometrical parameters and varying dump position, while Figure $14 \mathrm{a}, \mathrm{b}$ shows the analysis results for different dump position at varying slope angles and excavation depths. From Figure 13a, b it can be seen that the surface mine key geometrical parameters in a composite slope system have an inverse relationship to the factor of safety. However, it can be seen from Figure 14a, b, that the dump position has a direct relationship with the factor of safety. From Figure 13a, it is seen that when the dump position $d=50 \mathrm{~m}$ lower FS values are obtained than for $d=100 \mathrm{~m}$. However, when $d=200 \mathrm{~m}$, the numerical simulation produces higher factor of safety than for $d<200 \mathrm{~m}$. Figure $13 b$ depicts similar trend in the FS value when the dump position is coupled with the slope angle. Therefore, lower dump position produces lower FS value than dump constructed further away from the crest of a slope.

Even though the factor of safety decreases with the increase in excavation depth, Figure 13a, shows that there exists a critical break point in the influence curve for each dump position when coupled with the excavation depth and this critical break point occurs at $H=75 \mathrm{~m}$. The break point in the influence rule is related to the transition between one influencing parameter to the other. Since the dump position is a function of the loading condition, it can be said that the dump position has an indirect influence on the excavation depth but a direct relationship with the factor of safety. (a)

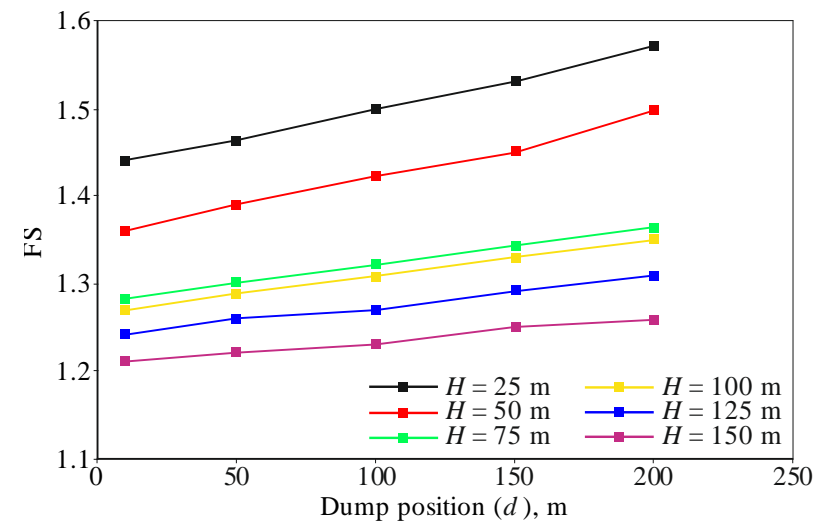

(b)

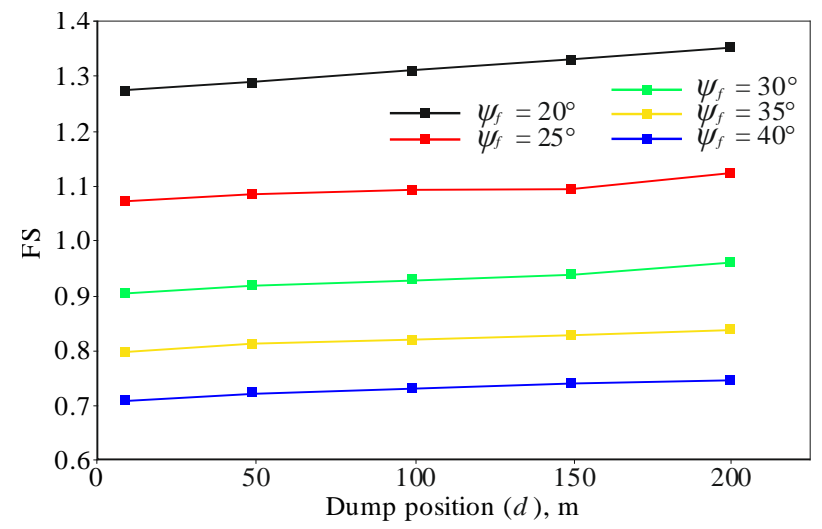

Figure 14. Factor of safety for different dump position at varying excavation depth and slope angle

For the influence rule shown in Figure 13b, the direct influence pattern between the factor of safety and the slope angle is obtained. The factor of safety directly reduces with an increase in the slope height.

From figure 14a, it is seen that when the excavation depth $H=25 \mathrm{~m}$ higher FS values are obtained than for $H=75 \mathrm{~m}$. Similarly, when the excavation depth is increased to $H=150 \mathrm{~m}$, the factor of safety further decreases than for models with $H<150 \mathrm{~m}$. Figure $14 \mathrm{~b}$ depicts far slower growth in the FS curve than for the influence rule shown in Figure 14a. The reason is obvious; the relationship between the excavation depth and the factor of safety is more direct than the relationship between the dump position and the slope angle to the factor of safety. However, the factor of safety increases with increase in dump position even when the dump position is coupled with the slope angle. It is also seen from Figure 14b that steep slopes produces lower FS than slope with lower angles.

\subsection{Improvement in stability due to dump position and surface mines geometrical parameter coupling interactions}

By understanding the influence and changes in the FS values due to the interaction between the dump position and a surface mines geometrical parameter the factor of safety of a composite slope can be improved greatly; hence the stability of the system. Figure 15a, b illustrates a 3D data plot of the dump position, and surface mines geometrical parameters as contour outlines in 2D space. In Figure 15a, the vertical axis represents the dump position while the $\mathrm{x}$-axis shows the dumping height. 
(a)

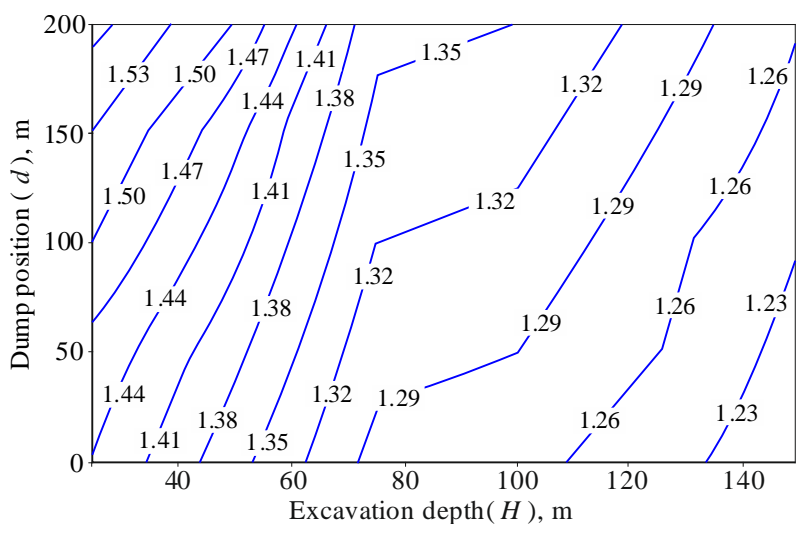

(b)

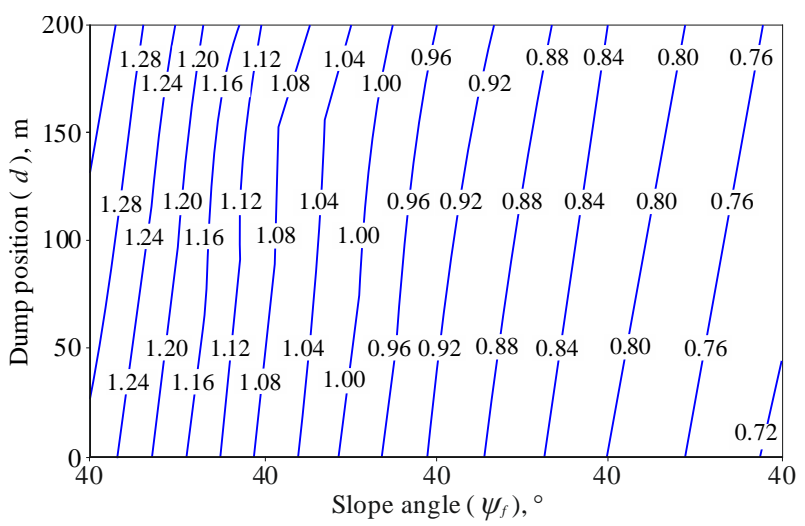

Figure 15. 3D Data plot of dump position, and Surface mines geometrical parameters as contour outlines in $2 D$ space

As moving along the vertical axis from the point of origin $(20,0)$, the factor of safety increases with increase in dump position while it decreases along the $\mathrm{x}$-axis with increase in excavation depth. Similarly, it is seen from Figure 15b, that moving along the vertical axis from the point of origin (20, 0 ), the factor of safety increases with increase in dump position and decreases along the $\mathrm{x}$-axis with increase in dump angle. The rate of increase in the factor of safety when the dump position and the excavation depth is coupled is far greater then when the slope angle is coupled with the dump position. However, considering an abscissa and ordinate values within the $2 \mathrm{D}$ space a conclusion can be drawn on how the FS behaves when the excavation depth is coupled with the dump position. From Figure $15 \mathrm{a}$, when $d=50 \mathrm{~m}$ and moves along the $\mathrm{x}$-axis where $H=100 \mathrm{~m}$ the obtained factor of safety FS = 1.29; however, when the dump position is increased to $d=150 \mathrm{~m}$ the factor of safety increases to $\mathrm{FS}=1.32$.

If the dump position has to be maintained at $d=50 \mathrm{~m}$ and moving along the $\mathrm{x}$-axis such that $H=150 \mathrm{~m}$, the obtained factor of safety is FS $=1.23$, thus it can be seen that the coupling of low excavation depths with lower dump position, produces higher factor of safety than higher excavation depths with lower dump positions. Secondly, when $H=100 \mathrm{~m}$ and $d=50 \mathrm{~m}$ the factor of safety FS $=1.23$, nevertheless when the dump position is increased from $d=50 \mathrm{~m}$ to $d=200 \mathrm{~m}$, the factor of safety increases to $F S=1.25$, indicating that the coupling of high dump height with high dump position increases the factor of safety. Furthermore, a conclusion can be drawn that how the FS behaves when the slope angle is coupled with the dump position by analyzing Figure $15 \mathrm{~b}$.
From Figure $15 \mathrm{~b}$, when $d=50 \mathrm{~m}$ and moving along the $\mathrm{x}$-axis where $\psi_{f}=20^{\circ}$ the obtained factor of safety $\mathrm{FS}=1.28$; however, when the dump position is increased to $d=150 \mathrm{~m}$ the factor of safety increases to $\mathrm{FS}=1.33$. If the dump position has to be maintained at $d=50 \mathrm{~m}$ and moving along the $\mathrm{x}$-axis such that $\psi_{f}=40^{\circ}$, the obtained factor of safety is FS $=0.72$, thus the coupling of low slope angles with lower dump position, produces higher factor of safety than steeper slope angles and lower dump positions. Secondly, when $\psi_{f}=40^{\circ}$ and $d=50 \mathrm{~m}$ the factor of safety is $\mathrm{FS}=0.72$, nevertheless when the dump position is increased from $d=50 \mathrm{~m}$ to $d=200 \mathrm{~m}$, the factor of safety increases to FS $=0.75$, indicating that the coupling of steep slope angles with high dump position can improve the factor of safety significantly. Hence, it can be seen from the results that in order to enhance stability and increase the factor of safety when the slope geometrical parameters are the determinant factors influencing stability in a composite slope system the position of the dump within the system plays a critical role.

\section{Conclusions}

The general trend obtained from the analysis results is such that the excavation depth has an inverse relationship to the factor of safety.

A rule of thumb can be drawn from the assertion made in order to improve stability within any given surface mines that is deep excavation should be created with lower slope angles and steep slope angles with shallower excavation depths. By understanding the influence and changes in the FS values due to the interaction between the surface mines key geometrical parameters can help engineers and managers in making sound decision regarding parametric selection.

The analysis results has shown that the dump height and angle are two parameters with functional relationship.

The results show the influential break point where the dump height have a significant influence on the factor of safety.

Finally, it can be concluded that by understanding the coupling interactions between the upper and lower limits of the surface mines geometrical parameters and the dumping heights can improve the factor of safety significantly; thus, the stability of the system.

It is concluded that the influence of the dump position is a function of the loading condition.

It can be seen from the results that in order to enhance stability and increase the factor of safety when the dump key geometrical parameters are the determinant factors influencing stability in a composite slope system the position of the dump within the system plays a critical role.

The factor of safety increases with increase in dump position even when the dump position is coupled with the slope angle.

It can be seen from the results that in order to enhance stability and increase the factor of safety when the slope geometrical parameters are the determinant factors influencing stability in a composite slope system the position of the dump within the system plays a critical role.

\section{Acknowledgements}

The authors are thankful to everyone who supported during this research work. 


\section{References}

[1] Bacha, S., Barvor, Y.J., Qingxiang, C., Zhao, C.S., \& Wang, M (2020). Influence of composite slope geometrical parameters on soft rock slope stability. Mining of Mineral Deposits, 14(1), 112-119. https://doi.org/10.33271/mining14.04.001

[2] Bacha, S., Long, Z., Javed, A., \& Al Faisal, S. (2020). A review of rock burst's experimental progress, warning, prediction, control and damage potential measures. Journal of Mining and Environment, 11(1), 31-48. https://doi.org/10.22044/jme.2019.9092.1797

[3] McCarter, M.K. (1990). Design and operating considerations for mine waste embankments. In Surface Mining (Second Edition), 890-899. Littleton, United States: Society for Mining, Metallurgy and Exploration.

[4] Naylor, D.J. (1982). Finite elements and slope stability. In Numerical Methods in Geomechanics, 229-244. Boston, United States: D. Reidel Publishing Company. https://doi.org/10.1007/978-94-009-7895-9 10

[5] Chaney, R., Demars, K., Pelkey, S., Valsangkar, A., \& Landva, A. (2001). Shear displacement dependent strength of municipal solid waste and its major constituent. Geotechnical Testing Journal, 24(4), 381. https://doi.org/10.1520/GTJ11135J

[6] Pande, G.N., Beer, G., \& Williams, J.R. (1990). Numerical methods in rock mechanics. Hoboken, United States: John Wiley \& Sons LTD.

[7] Zienkiewicz, O.C., Kelly, D.W., \& Bettess, P. (1977). The coupling of the finite element method and boundary solution procedures. International Journal for Numerical Methods in Engineering, (11), 355-75. https://doi.org/10.1002/nme.1620110210

[8] Zou, J.Z., Williams, D.J., \& Xiong, W.L. (1995). Search for critical slip surfaces based on finite element method. Canadian Geotechnical Journal, (32), 233-246. https://doi.org/10.1139/t95-026

[9] Pariseau, W.G. (2012). Design analysis in rock mechanics. London, United Kingdom: Boca Raton, CRC Press/Balkema. $\underline{\text { https://doi.org/10.1201/b11461 }}$

[10] Wang, J., \& Peng, C.J. (2013). Macro-mechanical parameters analysis of rock slope based on the partition classification method. Advanced Materials Research, (790), 310-315. https://doi.org/10.4028/www.scientific.net/AMR.790.310

[11] Salmasi, F., Pradhan, B., \& Nourani, B. (2019). Prediction of the sliding type and critical factor of safety in homogeneous finite slopes. Applied Water Science, 9(7). https://doi.org/10.1007/s13201-019-1038-1

[12] Tang, G., Zhao, L., Li, L., \& Yang, F. (2015). Stability charts of slopes under typical conditions developed by upper bound limit analysis. Computers and Geotechnics, (65), 233-240. https://doi.org/10.1016/j.compgeo.2014.12.008

[13] Wang, L., \& Long, F. (2014). Base stability analysis of braced deep excavation in undrained anisotropic clay with upper bound theory. Science China Technological Sciences, 57(9), 1865-1876. https://doi.org/10.1007/s11431-014-5613-2

[14] Bolla, A., \& Paronuzzi, P. (2019). Geomechanical field survey to identify an unstable rock slope: the Passo Della Morte case history (NE Italy). Rock Mechanics and Rock Engineering, 53(4), 15211544. https://doi.org/10.1007/s00603-019-01963-w
[15] Jordá-Bordehore, L. (2017). Application of Q slope to assess the stability of rock slopes in Madrid Province, Spain. Rock Mechanics and Rock Engineering, 50(7), 1947-1957. https://doi.org/10.1007/s00603-017-1211-5

[16] Kumar, V., Himanshu, N., \& Burman, A. (2019). Rock slope analysis with nonlinear hoek-brown criterion incorporating equivalent MohrCoulomb parameters. Geotechnical and Geological Engineering, 37(6), 4741-4757. https://doi.org/10.1007/s10706-019-00935-9

[17] Dawson, E.M., Roth, W.H., \& Drescher, A. (1999). Slope stability analysis by strength reduction. Geotechnique, 49(6), 835-840. https://doi.org/10.1680/geot.1999.49.6.835

[18] Griffiths, D.V., \& Lane, P.A. (1999). Slope stability analysis by finite elements. Geotechnique, 49(3), 387-403. https://doi.org/10.1680/geot.1999.49.3.387

[19] Hoek, E. (1986). General two-dimensional slope stability analysis. Analytical and computational methods in engineering rock mechanics. London, United Kingdom: Allen \& Unwin Ltd.

[20] Lorig, L.J., \& Brady, B.H.G. (1982). A hybrid discrete elementboundary element method of stress analysis [C]. Proceedings of the $23^{\text {rd }}$ US Symposium on Rock Mechanics, 628-636.

[21] Farias, M.M., \& Naylor, D.J. (1998). Safety analysis using finite elements. Computers and Geotechnics, (22), 165-181. https://doi.org/10.1016/S0266-352X(98)00005-6

[22] Naghadehi, M.Z., Jimenez, R., KhaloKakaie, R., \& Jalali, S.M.E. (2011). A probabilistic systems methodology to analyze the importance of factors affecting the stability of rock slopes. Engineering Geology, (118), 82-92. https://doi.org/10.1016/j.enggeo.2011.01.003

[23] Owen, D.R.J., \& Hinton, E. (1980). Finite elements in plastisity: Theory and practice. Swansea, United Kingdom: Pineridge Press Limited.

[24] Perzyna, P. (1966). Fundamental problems in viscoplasticity. Advances in Applied Mechanics, (9), 243-377. https://doi.org/10.1016/S00652156(08)70009-7

[25] Rachez, X., Billaux, D., \& Hart, R. (2002). Slope stability analysis with integrated shear strength reduction algorithm. In Numerical Methods in Geomechanical Engineering. Paris, France: Presses de I'ENPC/LCPC.

[26] Hammah, R.E., Yacoub, T., \& Corkum, B. (2008). The practical modelling of discontinuous rock masses with finite element analysis. Toronto, Canada: American Rock Mechanics Association RokcScience Inc.

[27] Nian, T.-K., Huang, R.-Q., Wan, S.-S., \& Chen, G.-Q. (2012). Threedimensional strength-reduction finite element analysis of slopes geometric effects. Canadian Geotechnical Journal, 49(5), 574-588. https://doi.org/10.1139/t2012-014

[28] Matsui, T., \& San, K.C. (1992). Finite element slope stability analysis by shear strength reduction technique. Soils and Foundations, 32(1), 59-70. https://doi.org/10.3208/sandf1972.32.59

[29] Morgenstern, N.R., \& Price, V.E. (1965). The analysis of the stability of general slip surfaces. Geotechnique, 15(1), 79-93. https://doi.org/10.1680/geot.1965.15.1.79

[30] Miščević, P., \& Vlastelica, G. (2014). Impact of weathering on slope stability in soft rock mass. Journal of Rock Mechanics and Geotechnical Engineering, 6(3),240-250. https://doi.org/10.1016/j.jrmge.2014.03.006

[31] Hsu, S., Hsieh, T., \& Tsai, P. (2019). Influence of material spatial variability on slope stability in soft rock. IOP Conference Series: Materials Science and Engineering, (615), 012044. https://doi.org/10.1088/1757-899X/615/1/012044

\section{Дослідження сукупного впливу геометричних параметрів композитного укосу}

\section{Я.Д. Барвор, Ш. Бача, Ц. Цінсян, Ч.Ш. Чжао, Н. Мохаммад, І.М. Джискані, Н. Хан}

Мета. Дослідження та аналіз сукупного впливу геометричних параметрів композитного укосу на його стійкість шляхом застосування чисельного моделювання методом кінцевих елементів.

Методика. Виділено основні параметри впливу композитного укосу на стійкість: кут укосу та глибина виробки разом з навантаженням (відвалом). На основі програми FLAC/Slope були побудовані й проаналізовані кілька моделей для визначення їх сукупного впливу та взаємодії.

Результати. Встановлено, що коли кут укосу та глибина виробки з'єднуються з таким фактором як навантаження відвалу, це призводить до проблем у виробничій безпеці. Відмічено, що правильне розміщення відвалу відіграє ключову роль в забезпеченні його стійкості. Визначено, що напруження, викликані відвалом, зменшуються в міру віддалення від гребня укосу, в той час як напруження в зоні активного впливу за відвалом зменшуються на умовній поверхні ковзання, а місце розташування відвалу в процесі формування композитного укосу забезпечує стійкість. Фактор безпеки має той же характер впливу для всіх параметрів, викликаних напруженням і правилом впливу. Загальна тенденція, отримана за результатами аналізу, така, що глибина виймання має зворотну залежність від коефіцієнта безпеки. Сформульовано практичне правило - глибоке виймання повинно бути створене 3 меншими кутами укосу і крутими кутами укосу з меншою глибиною виймання. Результати, отримані при аналізі напружень методом кінцевих елементів, схожі з даними аналізу стабільності укосу.

Наукова новизна. Вперше розглянуто сукупний вплив геометричних параметрів композитного укосу. Виявлено функціональний взаємозв'язок висоти та кута укосу. Встановлено, що коефіцієнт безпеки збільшується з підвищенням положення розвантаження, навіть коли розташування розвантаження збігається з кутом нахилу.

Практична значимість. Результати, отримані в ході даного дослідження, можуть бути ефективно використані для аналізу та проектування композитних укосів у м'яких породах відкритих кар'єрів.

Ключові слова: сукупний вплив, відвал, стабільність композитного укосу, характер впливу 


\section{Исследование совокупного воздействия геометрических параметров композитного откоса}

\section{Я.Д. Барвор, Ш. Бача, Ц. Цинсян, Ч.Ш. Чжао, Н. Мохаммад, И.М. Джискани, Н. Хан}

Цель. Исследование и анализ совокупного воздействие геометрических параметров композитного откоса на его устойчивость посредством применения численного моделирования методом конечных элементов.

Методика. Выделены основные параметры воздействия композитного откоса на устойчивость: угол откоса и глубина выработки вместе с нагрузкой (отвалом). На основе FLAC/Slope были построены и проанализированы несколько моделей для определения их совокупного воздействия и взаимодействия.

Результаты. Установлено, что когда угол откоса и глубина выработки соединяются с таким фактором как нагрузка отвала, это приводит к проблемам в производственной безопасности. Отмечено, что правильное размещение отвала играет ключевую роль в обеспечении его устойчивости. Определено, что напряжения, вызванные отвалом, уменьшаются по мере удаления от гребня откоса, в то время как напряжения в зоне активного воздействия за отвалом уменьшаются на условной поверхности скольжения, а место расположения отвала в процессе формирования композитного откоса обеспечивает устойчивость. Фактор безопасности имеет тот же характер влияния для всех параметров, вызванных напряжением и правилом влияния. Общая тенденция, полученная по результатам анализа, такова, что глубина выемки имеет обратную зависимость от коэффициента безопасности. Сформулировано практическое правило - глубокая выемка должна быть создана с меньшими углами откоса и крутыми углами откоса с меньшей глубиной выемки. Результаты, полученные при анализе напряжений методом конечных элементов, схожи с данными анализа стабильности откоса.

Научная новизна. Впервые рассмотрено совокупное воздействие геометрических параметров композитного откоса. Выявлена функциональная взаимосвязь высоты и угла откоса. Установлено, что коэффициент безопасности увеличивается с увеличением положения разгрузки, даже когда положение разгрузки совпадает с углом наклона.

Практическая значимость. Результаты, полученные в ходе настоящего исследования, могут быть эффективно использованы для анализа и проектирования композитных откосов в мягких породах открытых карьеров.

Ключевые слова: совокупное воздействие, отвал, стабильность композитного откоса, характер влияния 